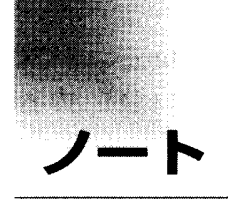

論文受付 月26日 論文受理 2005年 5 月24日

Code No. 254

\section{コンピューテッドラジオグラフィにおける グリッドライン検出・抑制処理GDSの臨床運用の有用性}

加藤元章・西村幸恵・岡本孝英1）・リチャード ヴァンメッター2) シャオフイ ワン ${ }^{3)} \cdot$ 伊知地宏志4) - 沢井美穂 ${ }^{4)}$

清岡 誠 ${ }^{4)} \cdot$ 池上裕子 ${ }^{4)}$

東京医科大学病院放射線部

1 ) 帝京大学医学部附属病院中央放射線部

2)イーストマンコダック社ヘルスイメージングリサーチラボ

3)イーストマンコダック社ヘルスイメージング研究開発センター

4)コダック株式会社へルスイメージング事業部

\section{緒 善}

X線を使用する撮影検査に抢いて，一部被写体厚の 薄い部位を除き散乱X線の除去を目的としたグリッド の使用は欠かせない.グリッドには散乱X線吸収物質 として鉛箔が使用されておう，静止グリッドとして使 用した場合，その鉛箔は写真上で縞目㓌影のグリッド ラインとして観察者に認識される。

これまでの診断メディアの主流であるフィルム/ス クリーンシステムでは，グリッドラインは規則正しい 線状除影と認識されるが，読影の妨げとなることは少 なかった。ところが，近年急速に発展してきたcomputed radiography (以下, CR) などのデジタル画像処理 では，鉛䇴の間隔と読み取り時のサンプリング間隔の 関係によってはエリアシング現象が生じ，グリッドラ インがフィルムやモニ夕上で干渉縞を形成する場合が あり，画像診断の大きな障害となる状況が発生してい る.

この問題を改善するため,これまでもローパスフィ ルタを使用しグリッドライン以上の周波数成分を除去 することで，画像に出現する干渉縞を防ぐ方法が提案

\title{
Clinical Efficacy of Image Processing of Grid Detection and Suppression(GDS) in Computed Radiography
}

\section{MOTOAKI KATO, SACHIE NISHIMURA, TAKAHIDE OKAMOTO, ') RICHARD L. VANMETTER, ${ }^{2)}$ XIAOHUI WANG,3) HIROSHI ICHIJI,4) MIHO SAWAI,4) MAKOTO KIYOOKA,4) and YUKO IKEGAMI ${ }^{4)}$}

\author{
Department of Radiology. Tokyo Medical University Hospital \\ 1 ) Department of Radiology, Teikyo University Hospital \\ 2)Eastman Kodak Company Health Imaging Research Laboratory \\ 3) Eastman Kodak Company Health Imaging Research and Development \\ 4) Kodak Japan, Ltd., Health Imaging Division \\ Received Oct. 26, 2004; Revision accepted May 24, 2005; Code No. 254
}

\section{Xumary}

In projection radiography, stationary grids are indispensable accessories to the improvement of diagnostic imaging. On the other hand, they are becoming one of the issues facing digital image processing. The lead foil that composes the grid can produce moiré on printed films and monitors according to the sampling interval at which the image is read by computed radiography $(\mathrm{CR})$, creating a major obstacle to diagnosing images. The subject of this study on Grid Detection and Suppression(GDS) was the development of comprehensive image-processing software to detect and suppress grid lines automatically. Our results showed that applying GDS parameters 3 5 could provide a sufficient effect on suppression with little impact on images through the use of a multi-purpose grid (grid ratio $8: 1$, density $34 \mathrm{lp} / \mathrm{cm}$ ) for general purposes. In projection radiography, it is expected that soft copy diagnosis will increase because the digital transition is proceeding, and the establishment of high-speed networks is becoming easier. Therefore, the digital environment is expected to improve and the choice of grids and monitors to expand, by using software such as GDS that does not require special skills.

1.4ty words: Computed radiography, Anti-scatter grid, Moiré, Aliasing

別刷資料請求先：干160-0023 東京都新宿区西新宿6-7-1

東京医科大学病院 放射線部 加藤元章 宛 
されている1,2)。しかし，この手法を用いた場合，グ リッドライン以上の高い周波数成分で構成される被写 体情報まで取り去るため，画像情報の損失を招く可能 性が避けられない。

イーストマンコダック社では，グリッドラインを検 出しバンドストップフィルタを用いることでグリッド ライン周波数を抑制し，診断上必要とされる画質には ほとんど影響を及ぼさずに干渉縞を低減させる新しい ソフトウェアであるGrid Detection and Suppression(以 下，GDS）を開発した3，4〉.

今回の研究は，開発者の協力を得ることによりその 理論と特性を理解し，このソフトウエアを今後有効活 用していくため，干渉縞低減の効果と画像に対する影 響を検証し，日常業務のなかで使用するうえでの適切 なパラメータを探ることを目的とした。

\section{GDSの理論}

GDSはグリッドラインの検出と抑制という二つの骨 子となる機能を有するため，それぞれの動作原理につ いて概要を述べる.

GDSにおける第1 過程であるグリッドライン検出の アルゴリズムํ'は，フーリエ変換を使用した周波数解 析に基づき処理される。画像からグリッドラインが検 出されると，その画像は第 2 過程である抑制過程に送 られ，抑制処理後あるいは第 1 過程でグリッドライン が検出されない場合は，CRの基本的な画像好理であ る階調処理およびエッジ強調処理過程に送られる。

\section{1-1 グリッドラインの検出}

グリッドライン検出アルゴリズムに求められる基本 的要件を走す。

(1) 静止グリッドの存在の有無を正確に検出すること

(2) 静止グリッドの周波数と方向を的確に規定するこ と

(3)処理時間が高速であること

GDSが搭載されたCR装置に拉いて，画像デー夕は グリッドの有無にかかわらずグリッドライン検出処理 過程を通過する。したがって，この処理過程の速度が 遅くなることは，全画像処理過程のボトルネックとな る可能性がある。また，グリッドを使用していないに もかかわらずグリッドが存在すると䛊って判断された 場合，この画像は必要としないグリッド抑制処理過程 に送られることとなり，画像処理全体の速度低下をき たす要因となる。そのため，検出処理過程における速 度向上と，グリッドライン検出の精度を向上させるこ とはGDSの価值を高めるために不可欠な要素である。

Fig. 1にGDS検出プロセスの凹つの構成要素を示す.

\section{1-1-1 解析領域の決定}

第1のステップは，グリッドラインを検出するため の領域 (region of interest以下，ROI）を選択することで ある。このプロセスは画像サイズ・処理速度・検出限 界・検出精度に影響を及ぼす。GDSに拈けるグリッド ライン検出の手法は，フーリ工変換を使用した周波数 解析に基づいており，ROIを2の累乗の正方形とした 場合に最も高速な処理が可能である。実際には，サブ サンプリングした画像において，グリッドラインの強 度がより強く現れる，直接線が照射された部分のよう な散乱線が少ない領域から，2010乗である1024x 1024のROIが選択される. 画像の周辺領域は, フォス ファースクリーンのシリアルナンバーやマーカが画像 内に入り达む可能性があるためROIからは除外され る. GDSによって自動的に決定された検出領域の一例 をFig. 2に示す。

\section{1-1-2 パワースペクトルの取得}

第 2 のステップでは, X方向・Y方向に含まれるす ベてのラインのパワースペクトルを方向ごとに合計 し，それぞれの方向の平均した1Dパワースペクトル を算出する．Fig. 3にカセッテの長短軸に沿ったスぺ クトル解析過程を示す.

グリッドラインとピクセルのアライメントが命致し ていない場合，グリッドラインの位相がシフトしてし まう可能性があるが，平均した1Dパワースペクトル を得ることにより，グリッドライン検出の精度を改善 することが可能である。

\section{1-1-3 グリッド候補の特性解析}

グリッドライン検出の第 3 のステップは，グリッド の候補と考えられるすべてのピーク执よびその特性を 1Dパワースペクトルから探索するプロセスである. それぞれのスペクトルは，雑音を減少させるためにガ ウス重畳積分によりあらかじめスムージング処理され る。その後, 们形カーネルを用いたモルフォロジカル オープニングフィルタ処理を適用することでバックグ ラウンドを特定し，才リジナルとの差分を求め特異な スペクトルピークのみを分離する。 円形カーネルのサ イズは，後に続くエネルギー計算誤差の繰り越しを最 小限にするため，最も広いピーク幅の数倍のサイズと する必要がある。これはグリッドライン周波数が高周 波帯域に存在し，そのエネルギーが相対的に高い場 合，画像に德影響を及ぼすため，あらかじめ既定され た強度と周波数を超えるすべてのピークを検出する必 要があるためである.

分離されたスペクトルピークに対し，パラメトリッ ク手法により相対周波数, 強度, ピークの半值幅, エ ネルギー干渉およびトータルエネルギーなどのピーク 特性を解析することでグリッドラインと予測される候 


\begin{tabular}{|c|c|c|c|}
\hline $\begin{array}{l}\text { Determine } \\
\text { region of } \\
\text { interest }\end{array}$ & $\begin{array}{l}\text { Calculate one- } \\
\text { dimensional power } \\
\text { spectrum in both } \mathrm{x} \\
\text { and y directions }\end{array}$ & $\begin{array}{l}\text { Identify all } \\
\text { candidate grid } \\
\text { frequencies \& } \\
\text { characteristics }\end{array}$ & $\begin{array}{l}\text { Select most } \\
\text { likely grid } \\
\text { frequency and } \\
\text { orientation }\end{array}$ \\
\hline
\end{tabular}

Fig. 1 GDS detection process flow chart.

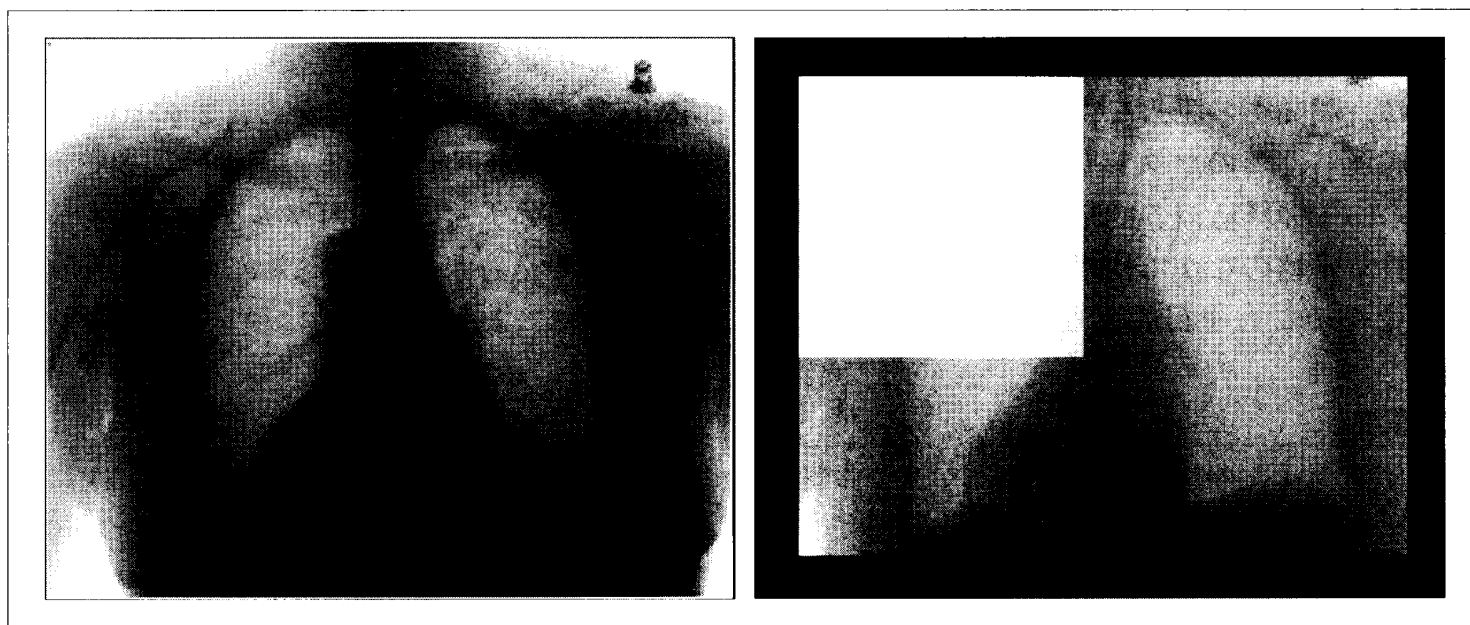

Fig. 2 (a) Original image.

(b) Same image as in (a) showing the highlighted region of interest. Note exclusion of the image boundary shown in black.

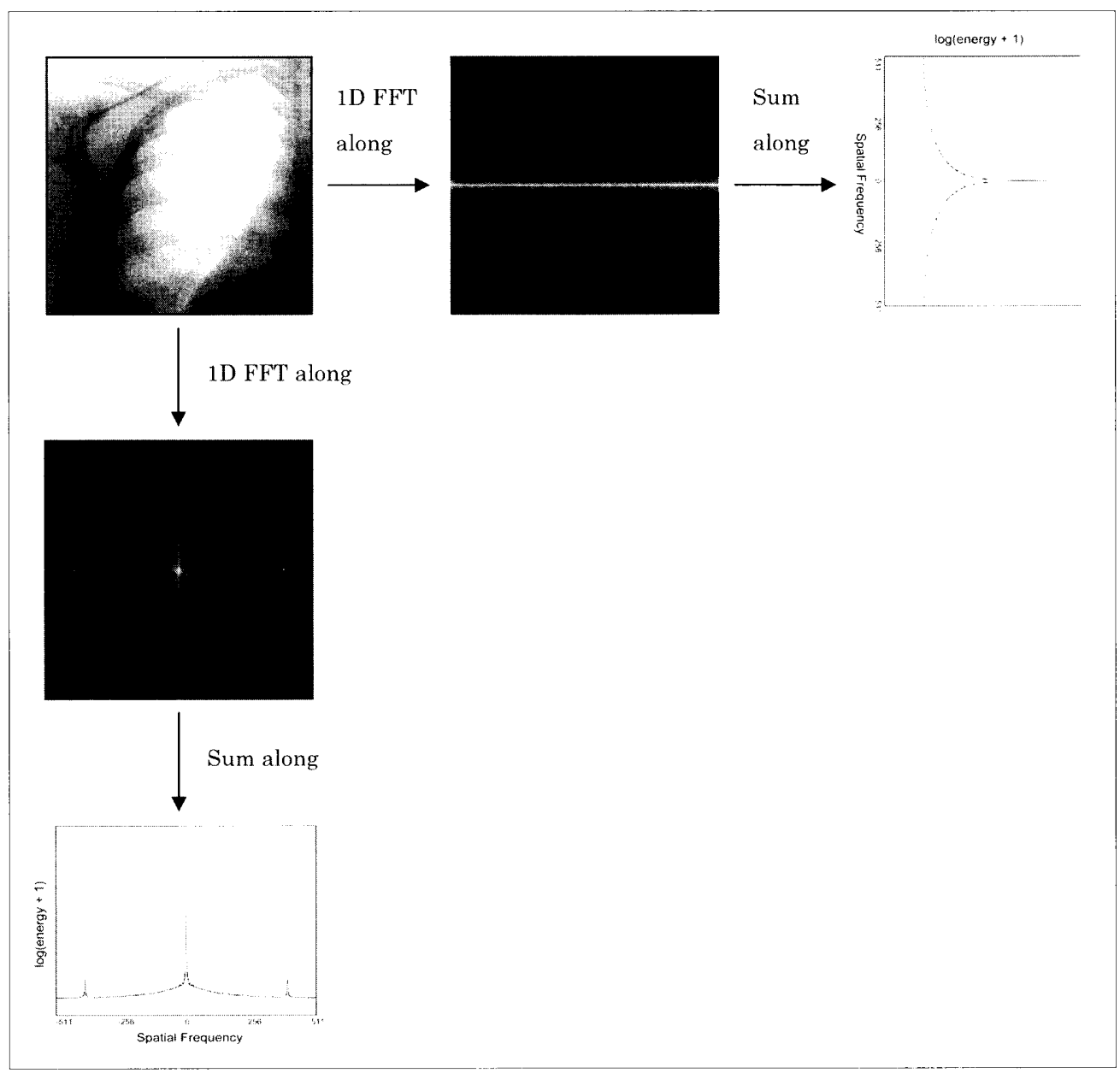

Fig. 3 Power spectrum analysis using one-dimensional FFT. 
補を選択し，各々のパワースペタトルについて，最も 高いエネルギーを持ついくつかのピークが次の解析過 程に送られる。

\section{1-1-4 周波数および方向の特定}

グリッドライン検出の最終段階となる第4 のステッ プでは，相対周波数とエネルギー干渉性の加重加算に ついてより詳細な解析を行い，あらかじめ既定された 閾值を超えたピークがグリッドライン周波数としてラ ンクされる。ランクリストがゼロであるという結果が 得られた場合はグリッドラインが検出されなかったと いうことになる。

\section{1-2グリッドラインの抑制}

グリッドライン抑制のアルゴリズム4゙は，最も有意 であると検出されたグリッドライン周波数に対し, 垂

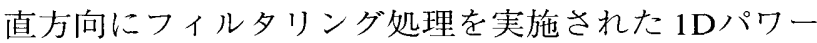
スペタトルに基づいている，原画像の損失を最小に抑 え，グリッドラインを最大に抑制する手法として，ノ ッチフィルタが採用されている。このノッチフィルタ はバンドストップフィルタの 1 種であり，特定の周波 数に急峻な減衰を与えることが可能なフィルタであ る.グリッドピーク抑制レベル, カッティングスロー プエッジ，インパルス応答速度などを含むフィルタパ ラメータは，グリッド抑制の最大化およびギブス現象 の最小化のために最適化される。

Belykhらの研究結果から, 最適なフィル夕選択はブ ロックコンボリュージョンを使用したFIR (Finite Impulse Response) Potterノッチフィルタであることが判 明している3)。一般的にリカーシブIIR (Infinite Impulse Response) フィルタはFIRフィルタよりも速い演算速度 を有していると考えられている。しかし，許容できな い位相シフトが発生してしまうことが分かっている。 ブロックコンボリュージョンアルゴリズムを使用する ことによりFIRフィルタの演算速度が问上することが 判明している5).

ノッチフィルタはグリッドライン周波数よりも高い 空間周波数帯域を保持するためにも有効である。ノッ チフィルタにとって最も重要なパラメータは帯域阻止 幅(バンドストップ幅)である。これはグリッドアーチ ファクト除去と画像損失の両方に影響を及ぼす。一般 的に，バンドストップ幅は狭い方がグリッドラインを より選択的に抑制するが，ギブス現象により原画像に 対するひずみも大きくなってしまう。また，バンドス トップ幅を広くすると，ギブス現象によるひずみは抑 えられるが，原画像に対する情報損失度合いが大きく なる(Fig. 4).

フィルタパフォーマンスを最適化するためにインテ ル社製のSignal Processing Library4.5を使用しており，
インテルMMX技術を組み合わせたPotterノッチフィル 夕によって効果的なグリッドアーチファクトの抑制, ギブス現象の最小化，そして高速処理が可能となって いる。グリッドラインの抑制度合いはsuppression level が16段階となるようパラメータ化されており（以下， GDSパラメータ，パラメータの值を示す場合GDS-を 使用する)，グリッドラインが検出された場合 1 ～16 のGDSパラメータから，画像に合わせて最適パラメー 夕を選択し調整することが可能である。

各GDSパラメータにおけるスペクトルパワー減衰量 をTable 1に示す.

\section{2. 方 法}

使用装置の一覧をTable 2に示す。

\section{2-1グリッドライン検出の検証}

コダックCRシステムに扮けるサンプリングピッチ はカセッテサイズにより異なり（Table 3)，干渉縞の発 生は使用するカセッテとグリッドの組み合わせによっ て変化すると考えられる．力セッテとグリッドの力向 を考えた場合，一般的にはカセッテの長軸に対しグリ ッドラインを平行に使用するが，状況によりグリッド ラインはサンプリングの方向に対しあらゆる角度を取 り得る。そこで，グリッド密度 $341 \mathrm{p} / \mathrm{cm}, 401 \mathrm{p} / \mathrm{cm}$, $601 \mathrm{p} / \mathrm{cm}$ の 3 種類のグリッドを各サイズのカセッテと 組み合わせ，サンプリング方向と平行，直交， $45^{\circ}$ と なるように配置したときの，それぞれのグリッドライ ン検出の成否を確認した。

また，X線束とグリッドの中心がずれた状況を想定

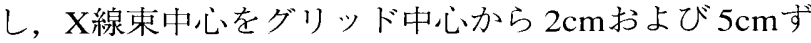
らした配置におういても同様に検証した，撮影には前腕 部のファントムを使用し撮影条件を $50 \mathrm{kV} \cdot 16 \mathrm{mAs}$ と した.

CR800では操作パネル上にGDSオプションスイッチ が配置されており，グリッドラインを検出した場合は ONとOFFが選択可能な状態となり，未検出であった 場合にはグレイアウトされ使用不可となる。そこで， グリッドライン検出の成否は, GDSオプションスイッ チが使用可能であるか否かによって確認した。

グリッド上の位置によりグリッドラインの間隔が異 なる可能性として，X線束とグリッドの中心がずれた 状況と同様，頭部夕ウン法のように，意四的にグリッ ドとのX線入射角度を大きく傾けて行う撮影が考えら れる．その場合のグリッドラインの検出を検証するた め，格子比8：1・密度 $341 \mathrm{p} / \mathrm{cm}$ のグリッドを用い50゚の 入射角で撮影した画像のグリッドライン周波数とパワ 一スペクトルを, 他の撮影状況による画像と比較し た. 実験にはすべて $24 \times 30 \mathrm{~cm}$ (四切)のカセッテを使用 


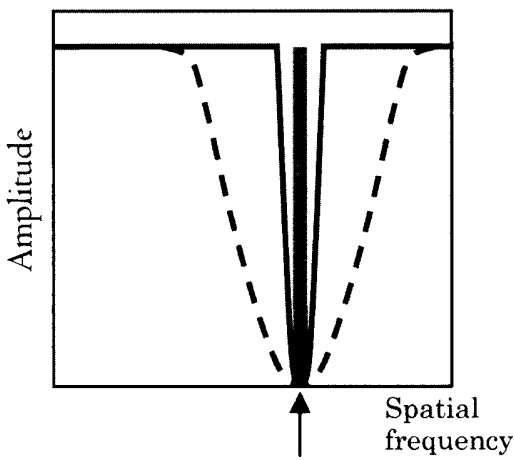

Grid line frequency

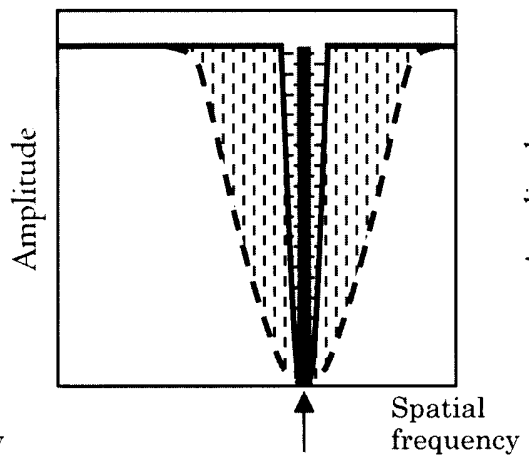

Grid line frequency

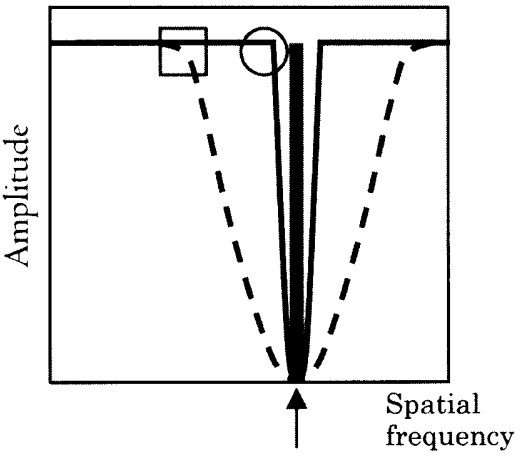

Grid line frequency

Fig. 4 Band stop width in notch filter and influence on image.

(a) Band stop width $A-$ and $B-\cdots .(A<B)$

(b) Loss of image information by $A$ : and $B$.

(c) Region where influence of Gibbs event incident is received by $A \bigcirc$ and $B \square$. (A>B)

Table 1 GDS parameter and spectrum power attenuation.

\begin{tabular}{|c|c|c|c|c|c|c|c|c|}
\hline $\begin{array}{c}\text { GDS } \\
\text { Parameter }\end{array}$ & 1 & 2 & 3 & 4 & 5 & 6 & 7 & 8 \\
\hline $\begin{array}{l}\text { Out//n } \\
\text { Power }\end{array}$ & $1 / 2^{2}$ & $1 / 4^{2}$ & $1 / 8^{2}$ & $1 / 13^{2}$ & $1 / 18^{2}$ & $1 / 30^{2}$ & $1 / 40^{2}$ & $1 / 50^{2}$ \\
\hline $\begin{array}{c}\text { GDS } \\
\text { Parameter }\end{array}$ & 9 & 10 & 11 & 12 & 13 & 14 & 15 & 16 \\
\hline $\begin{array}{l}\text { Out/In } \\
\text { Power }\end{array}$ & $1 / 63^{2}$ & $1 / 80^{2}$ & $1 / 100^{2}$ & $1 / 160^{2}$ & $1 / 220^{2}$ & $1 / 320^{2}$ & $1 / 500^{2}$ & $1 / 800^{2}$ \\
\hline
\end{tabular}

Table 2 Table of devices used.

\begin{tabular}{|c|c|c|}
\hline X-ray Generator & Toshiba & KXO-80G \\
\hline X-ray Tube & Toshiba & DRX-3724HD $1.1 \mathrm{mmAl}$ Target $0.6 \mathrm{~mm}$ \\
\hline CR device & Kodak & CR800 System3.0 \\
\hline Laser printer & Kodak & KELP2180 \\
\hline \multirow[t]{2}{*}{ Grid } & MITAYA & $\begin{array}{llll}5: 1 & 34 \mathrm{lp} / \mathrm{cm}, & 6: 1 \quad 34 \mathrm{lp} / \mathrm{cm} \quad 401 \mathrm{p} / \mathrm{cm} \\
8: 1 & 34 \mathrm{lp} / \mathrm{cm} & 401 \mathrm{p} / \mathrm{cm}, \quad 14: 1 \quad 601 \mathrm{p} / \mathrm{cm}\end{array}$ \\
\hline & JPI & $8: 1 \quad 341 \mathrm{p} / \mathrm{cm} \quad 401 \mathrm{p} / \mathrm{cm}, \quad 10: 1 \quad 601 \mathrm{p} / \mathrm{cm}$ \\
\hline
\end{tabular}

Table 3 Cassette size and sampling pitch in CR800.

\begin{tabular}{cc}
\hline \hline Cassette size & Sampling pitch \\
\hline $18 \times 24 \mathrm{~cm}$ & $97 \pm 2 \mu \mathrm{m}$ \\
$24 \times 30 \mathrm{~cm}$ & $115 \pm 2 \mu \mathrm{m}$ \\
$35 \times 35 \mathrm{~cm}$ & $168 \pm 2 \mu \mathrm{m}$ \\
$35 \times 43 \mathrm{~cm}$ & $168 \pm 2 \mu \mathrm{m}$ \\
\hline
\end{tabular}




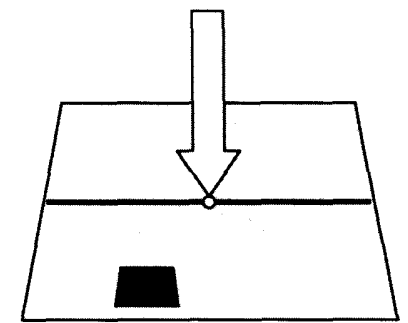

(1)

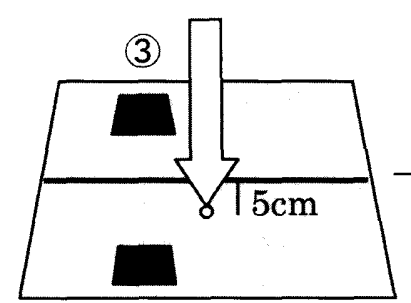

(2)
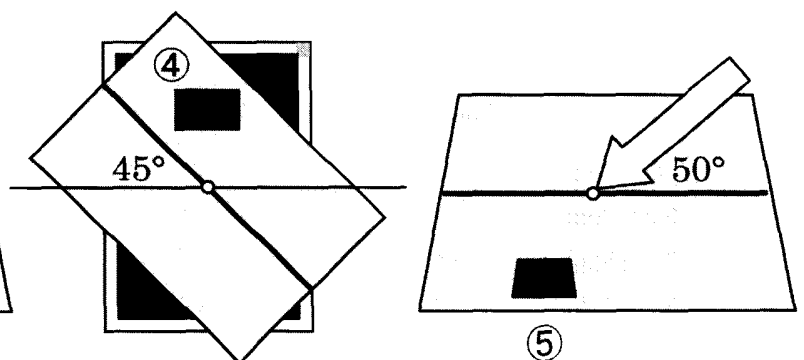

(5)

$\checkmark$ : X-ray exposure direction

$\circ$ : X-ray exposure point

Calculating area

Fig. 5 (a) Original image.

(b) Image that moves $X$-ray exposure point and grid center by $5 \mathrm{~cm}$.

(c) Image that rotates $45^{\circ}$ to cassette around grid.

(d) Oblique incidence image of $50^{\circ}$ to grid.

し，被写体には頭部ファントムを用いた。Fig. 5(a)〜 (d)に各画像の入射方向とグリッドの位置関係㧍よび それぞれの計算領域を示す。

\section{2-2 グリッドライン抑制の検証}

\section{2-2-1 物理評価}

評価の対象として, 散乱X線の影響を受けにくく， グリッドラインのスペクトルピークが比較的強く現 れ，GDSによる变化が観察しやすい部位として膝関節 を選択し，格子比8：1・密度34lp/cmのグリッドを用 い70kV・5mAsで撮影したDICOMデータに対し, GDS OFFおよびGDSパラメータを 1〜16まで変化さ せフーリエ変換による周波数解析を行い, 各パラメー 夕におけるグリッドラインのパワースペクトルの変化 を検証した。

\section{2-2-2 視覚評価}

視覚評価の第 1 ステップとして，物理評価で使用し た膝関節画像データをプリントし，2 肢強制選択法(2alternative forced choice以下，2-AFC法)6)の手法によ り，グリッドラインの信号の存在が不確かとなるGDS パラメータを検証した。実験に先立ち，研究にかかわ る数名の技師により選択の基準とする試料を決定する ための予備テストを行った，本実験での観察者は一般 撮影に携わる技師 20 名で行い，その経験年数は10年未 満10名，10年以上10名であった。

第 2 のステップとして，2-AFC法の結果を基に 3 種 類のGDSパラメータで試料となる写真を作成し，シエ ッフェの一対比較法 (中屋の変法) ${ }^{7}$ に従い画質の変化 を評価した。

試料として，格子比 $8: 1 \cdot$ 密度 $34 \mathrm{lp} / \mathrm{cm}$ のグリッド を用いて撮影した頸椎側面・肩関節正面・时関節正
面・腰椎側面・股関節正面の写真を使用し, それぞれ について微細構造物の描出度と軟部組織の粒状性の 2 点に注目し評価した。観察者は経験年数 10 年未満の技 師 8 名, 10年以上の技師 8 名, 10 年以上の放射線科 医 2 名, 整形外科医 2 名の 20 名であった。いずれの 視覚評価も輝度2900cdのシャウカステンを使用し, 照 度2340luxの環境で行った。

\section{3. 結 果}

\section{3-1 グリッドラインの検出}

各組み合わせにおけるグリッドラインの検出結果 を，検出、・未検出一としてTable 4 に示す. $35 \times 35 \mathrm{~cm}$ (大角) および $35 \times 43 \mathrm{~cm}$ (半切) と $601 \mathrm{p} / \mathrm{cm}$ の組み合わせ では，平行，直交ともに未検出であった。

今回使用したグリッドにおいて，同密度であれば格 子比の違いによる検出結果への影響はみられなかっ

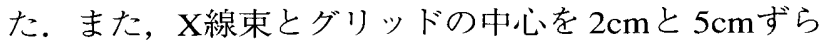
したそれぞれの実験では，中心を合わせたTable 4の結 果と比較して，いずれも変化はみられなかった。

頭部夕ウン法を想定した実験では，一般的に使用さ

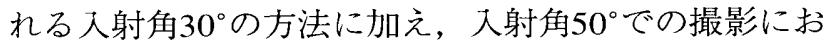
いてもグリッドラインの検出が確認できた. Fig. 5(a) 〜 (d)に示した，異なる撮影状況でのグリッド上の任 意の場所に扔けるグリッドライン周波数をTable 5に示 す。また，今回設定したそれぞれの計算領域における パワースペクトル強度は（3)>(1)>(2)>(4)>(5)の順であっ た。

\section{3-2 物理評価}

DICOMデータの周波数解析の結果, GDSの作用に よりグリッドラインのパワースペクトルが抑制されて 
Table 4 Result of the grid line detection by arrangement of a grid.

\begin{tabular}{|c|c|c|c|c|c|c|c|c|c|}
\hline & \multicolumn{3}{|c|}{$341 \mathrm{p} / \mathrm{cm}$} & \multicolumn{3}{|c|}{$40 \mathrm{lp} / \mathrm{cm}$} & \multicolumn{3}{|c|}{$601 \mathrm{p} / \mathrm{cm}$} \\
\hline & Parallel & Cross & $45^{\circ}$ & Parallel & Cross & $45^{\circ}$ & Parallel & Cross & $45^{\circ}$ \\
\hline $18 \times 24 \mathrm{~cm}$ & $\checkmark$ & $v^{\prime}$ & $\sqrt{ }$ & $\sqrt{\prime}$ & $v^{\prime}$ & $v^{\prime}$ & $v^{\prime}$ & $v^{\prime}$ & $\checkmark$ \\
\hline $24 \times 30 \mathrm{~cm}$ & $\sqrt{ }$ & $v^{\prime}$ & $v^{\prime}$ & $v^{\prime}$ & $v^{\prime}$ & $\checkmark$ & $v^{\prime}$ & $v^{\prime}$ & $\checkmark$ \\
\hline $35 \times 35 \mathrm{~cm}$ & $\checkmark$ & $\sqrt{ }$ & $\sqrt{\prime}$ & $\sqrt{\prime}$ & $v^{\prime}$ & $v^{\prime}$ & - & - & $\checkmark$ \\
\hline $35 \times 43 \mathrm{~cm}$ & $\checkmark$ & $\sqrt{ }$ & $\sqrt{\prime}$ & $\sqrt{\prime}$ & $\sqrt{\prime}$ & $v^{\prime}$ & - & - & $v^{\prime}$ \\
\hline
\end{tabular}

いることが確認できた。

Fig. 6に膝関節正面画像におけるパワースペク トルの変化を示す。（a）は2-AFC法の予備テスト として使用した画像であり，GDS OFFのピーク 值と比較し，GDS-7および16ではほぼTable 1で 示した設定値に減衰されていると確認される.

（b）は2-AFC法の結果から選択した 3 種類のGDS パラメータにより処理した画像である。

また，パワースペクトルピークの抑制にとも ない,グリッドライン周辺の空間周波数領域に おいてパワースペクトルの落ち込みがみられ た。

\section{3-3 視覚評価}

\section{3-3-1 2-AFC法}

今回のようなグリッド信号の有無を判定する 2-AFC法において，比較の基準とする試料に は，本来グリッド未使用の写真を選択するべき である。そこで，同じ被写体をグリッド未使用 にて撮影した写真を比較基準に用い，予備テス トとしての2-AFC法を行った。しかし，グリッ ドの有無それぞれのカセッテについて読み取り 処理を行った写真では，ヒストグラムの違いか ら画質に微妙な違いを生じ，すべてのGDSパラ メータにおいて，ほぼ違いを見分けてしまう結 果となった (Fig. 7(a)).

次に，グリッドを使用した写真のなかから， グリッドラインを見分ける可能性が低いと思わ れるGDS-16の写真を比較基準として同様の予備 テストを行った。しかし，グリッドライン周辺 の空間周波数の落ち込みが画質の変化として捉 えられ，グリッド未使用時と同様にほぼ違いを 見分けてしまう結果となった (Fig.7(b)).

そこで，グリッドラインのパワースペクトルのピー クが，本来被写体の持つレベルまで減衰され，グリッ ド未使用時の画像と比較しても, 特異なスペクトルピ ークとして認識することが困難と思われる，GDS-7の 写真を比較基準の試料として用いた (Fig. 7 (c))。
Table 5 Grid line spatial frequency in each calculating area.

\begin{tabular}{cccccc}
\hline Calculating area & (1) & (2) & (3) & (4) & (5) \\
\hline $\begin{array}{c}\text { Spatial frequency } \\
\text { (cycle/mm) }\end{array}$ & 3.29 & 3.26 & 3.26 & 2.31 & 3.26 \\
\hline
\end{tabular}

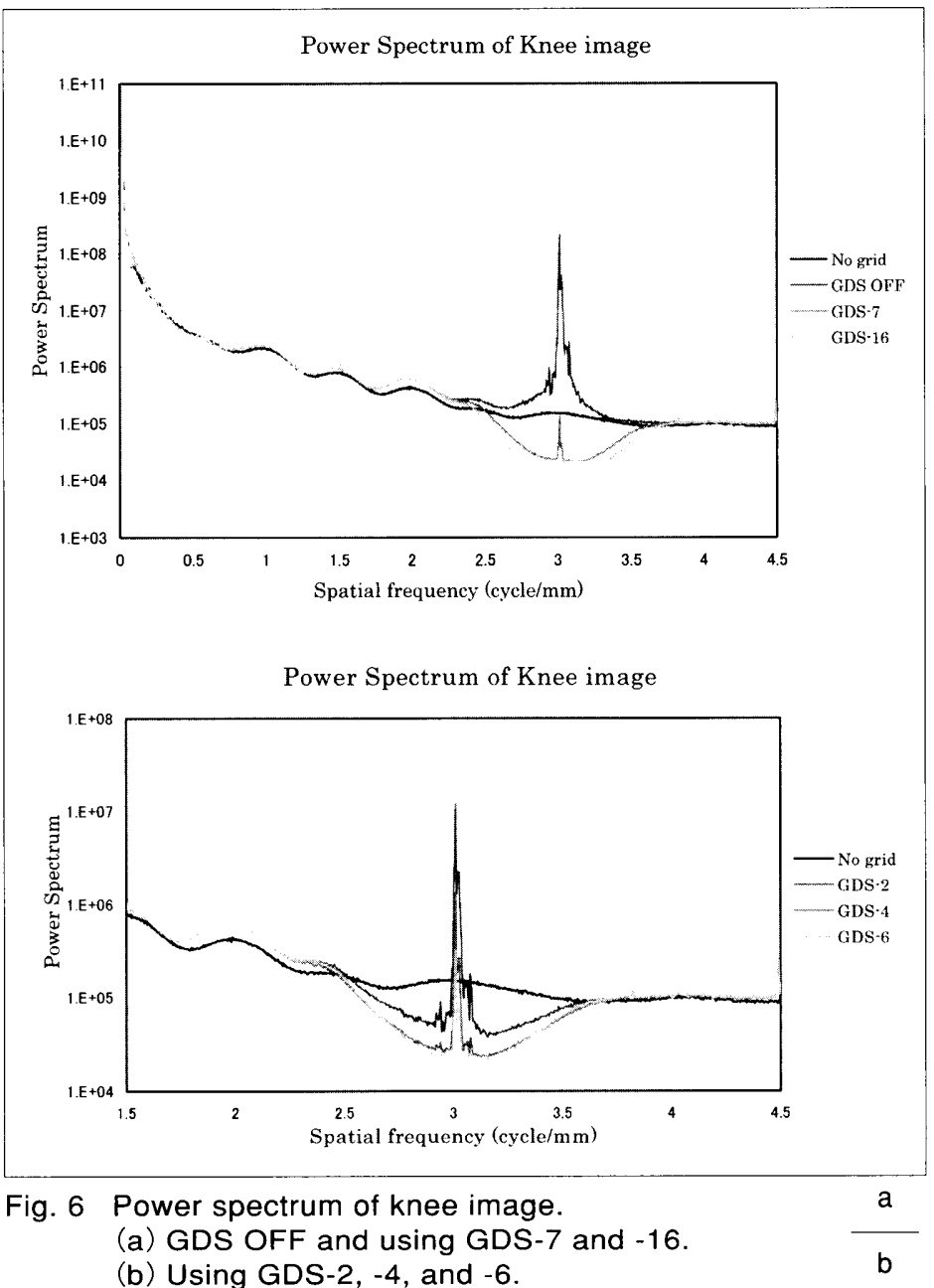

その結果, GDS-5の写真では, グリッドラインの信 号を的確に認識することがほぼ不可能となることが分 かった．Fig. 8にGDS-7の写真と比較したときの， GDS OFF抢よびGDS-1〜6のグリッドライン認識結果 を示す. 

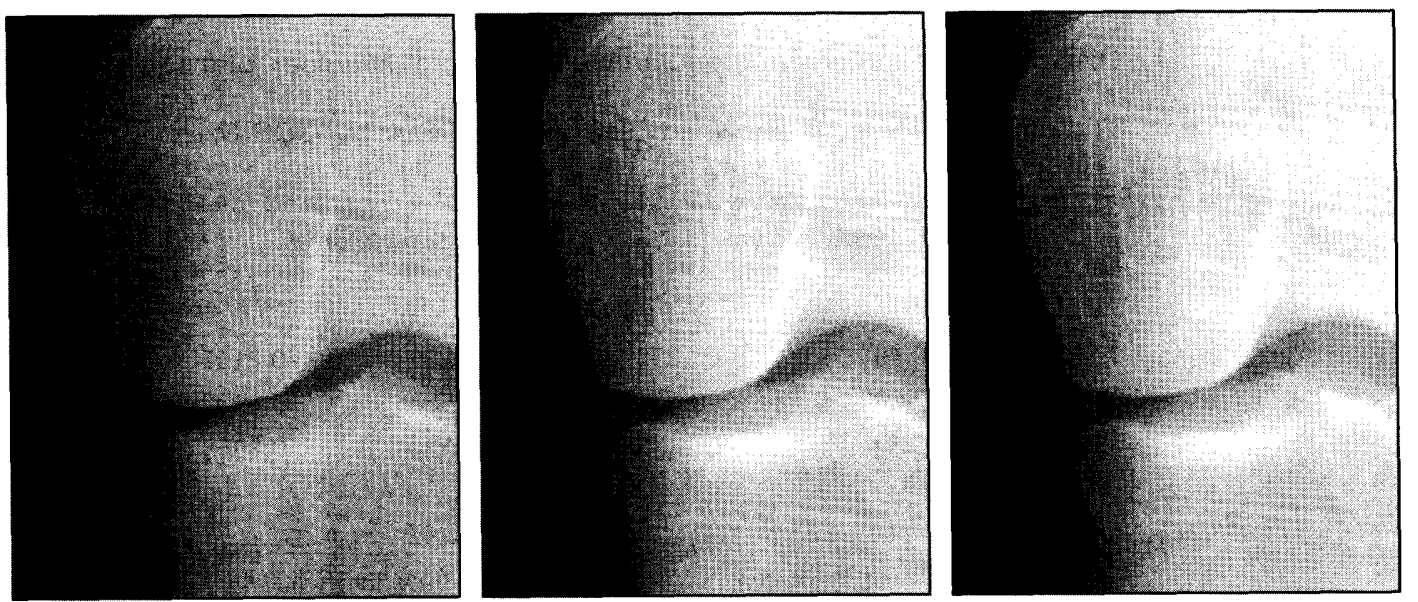

Fig. 7 Expansion display of the inside of knee joint.

(a) No Grid.

(b) Using GDS-16.

(c) Using GDS-7.

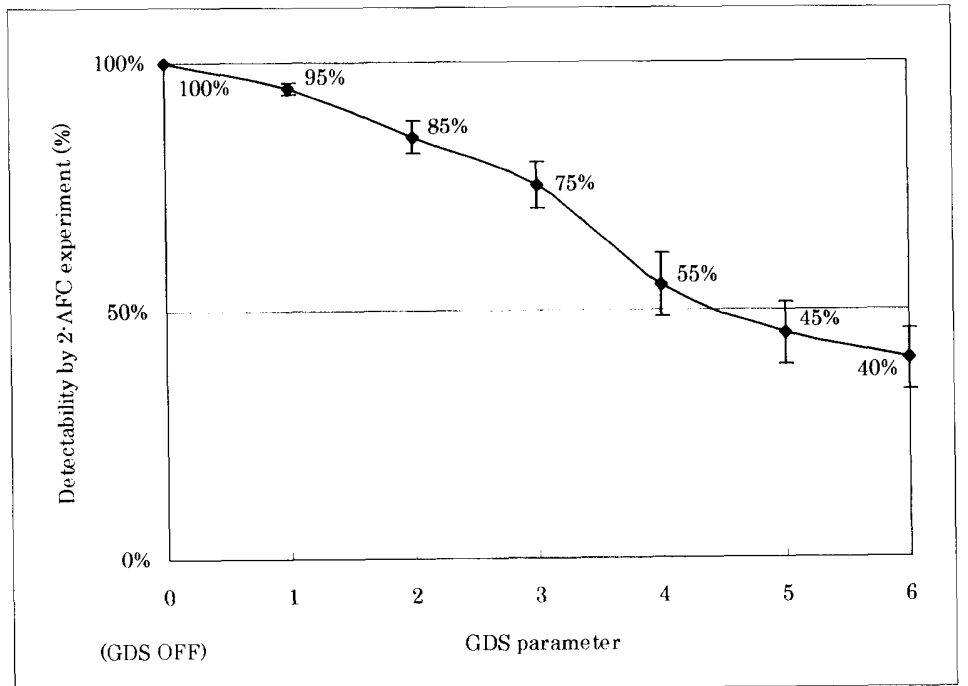

Fig. 8 Detectability of grid line detection of GDS-1 $\sim 6$ and GDS OFF by 2 -AFC experiment when image of GDS-7 is comparison criterion.

\section{3-3-2 一対比較法}

Table 6に，(a) 肩関節の微細構造物の描出度と (b)肩 関節の軟部組織の粒状性を評価した一対比較法の結果 を示す。それぞれGDS-2を $\alpha_{l}$, GDS-4を $\alpha_{2}$, GDS-6を $\alpha_{3}$ とした。 その結果，すべての $\left(\alpha_{i}-\alpha_{j}\right)$ で95\%・99\% のどちらの信頼区間においても有意差は認められなか つた。同時に比較テストを実施した他の試料について も同様の結果であった。

また, 評価の順位は (a) 肩関節の微細構造物の描出 度において $\alpha_{1}>\alpha_{2}>\alpha_{3}$, （b)肩関節の軟部組織の粒状性 評価では $\alpha_{2}>\alpha_{3}>\alpha_{1}$ であったが，他の試料での結果を含 めた全体で一律性はみられなかった．Fig.9に一対比 較法の試料として使用した写真のうち，肩関節正面揖 よび股関節正面の拡大像を示す。

\section{4. 考 察}

グリッドラインの検出結果について，密度 $601 \mathrm{p} / \mathrm{cm}$ のグリッドと大角または半切との組み合わせで，平 行，直交ともに未検出であった理由として，CR800で はそれらのサンプリングピッチが $168 \pm 2 \mu \mathrm{m}$ であり， $601 \mathrm{p} / \mathrm{cm}$ のグリッドライン間隔 $($ 約 $167 \mu \mathrm{m})$ よりも広い ことに起因する.

また，グリッドの配置と入射点のずれに関する実験 結果では，日常業務で想定されるグリッドの使用状況 下に拈いて，GDSのグリッドライン検出能が低下する などの変化はみられなかった。このことは，ベッド上 などグリッドとカセッテが不安定な状海トでの撮影時 においても，GDSが少なからず有効に働くものと期待 できる。 
Table 6 (a) Confidence interval in visibility evaluation of shoulder joint microstructure.

(b) Confidence interval in granularity evaluation of shoulder joint soft tissue.

The parameter used is shown in GDS-2: $\alpha_{1}$ GDS-4: $\alpha_{2}$ GDS-6: $\alpha_{3}$.

(a)

\begin{tabular}{ccccc}
\hline \hline \multirow{2}{*}{$\alpha_{i}-\alpha_{j}$} & \multicolumn{2}{c}{$95 \%$ Interval } & \multicolumn{2}{c}{$99 \%$ Interval } \\
\cline { 2 - 5 } & $\alpha_{i}-\alpha_{j}+Y_{0.05}$ & $\alpha_{j}-\alpha_{j}-Y_{0.05}$ & $\alpha_{i}-\alpha_{j}+Y_{0.05}$ & $\alpha_{i}-\alpha_{j}-Y_{0.05}$ \\
\hline$\alpha_{1}-\alpha_{2}=0.1833$ & 0.49 & -0.1233 & 0.5822 & -0.2155 \\
$\alpha_{1}-\alpha_{3}=0.2167$ & 0.5233 & -0.09 & 0.6155 & -0.1822 \\
$\alpha_{2}-\alpha_{3}=0.0333$ & 0.34 & -0.2733 & 0.4322 & -0.3655 \\
\hline
\end{tabular}

(b)

\begin{tabular}{ccccc}
\hline \multirow{2}{*}{$\alpha_{i}-\alpha_{j}$} & \multicolumn{2}{c}{$95 \%$ Interval } & \multicolumn{2}{c}{$99 \%$ Interval } \\
\cline { 2 - 5 } & $\alpha_{i}-\alpha_{j}+Y_{0.05}$ & $\alpha_{i}-\alpha_{j}-Y_{0.05}$ & $\alpha_{i}-\alpha_{j}+Y_{0.05}$ & $\alpha_{i}-\alpha_{j}-Y_{0.05}$ \\
\hline$\alpha_{1}-\alpha_{2}=-0.1333$ & 0.2764 & -0.5431 & 0.3997 & -0.6663 \\
$\alpha_{1}-\alpha_{3}=-0.1167$ & 0.2931 & -0.5264 & 0.4163 & -0.6497 \\
$\alpha_{2}-\alpha_{3}=0.0167$ & 0.4264 & -0.3931 & 0.5497 & -0.5163 \\
\hline
\end{tabular}
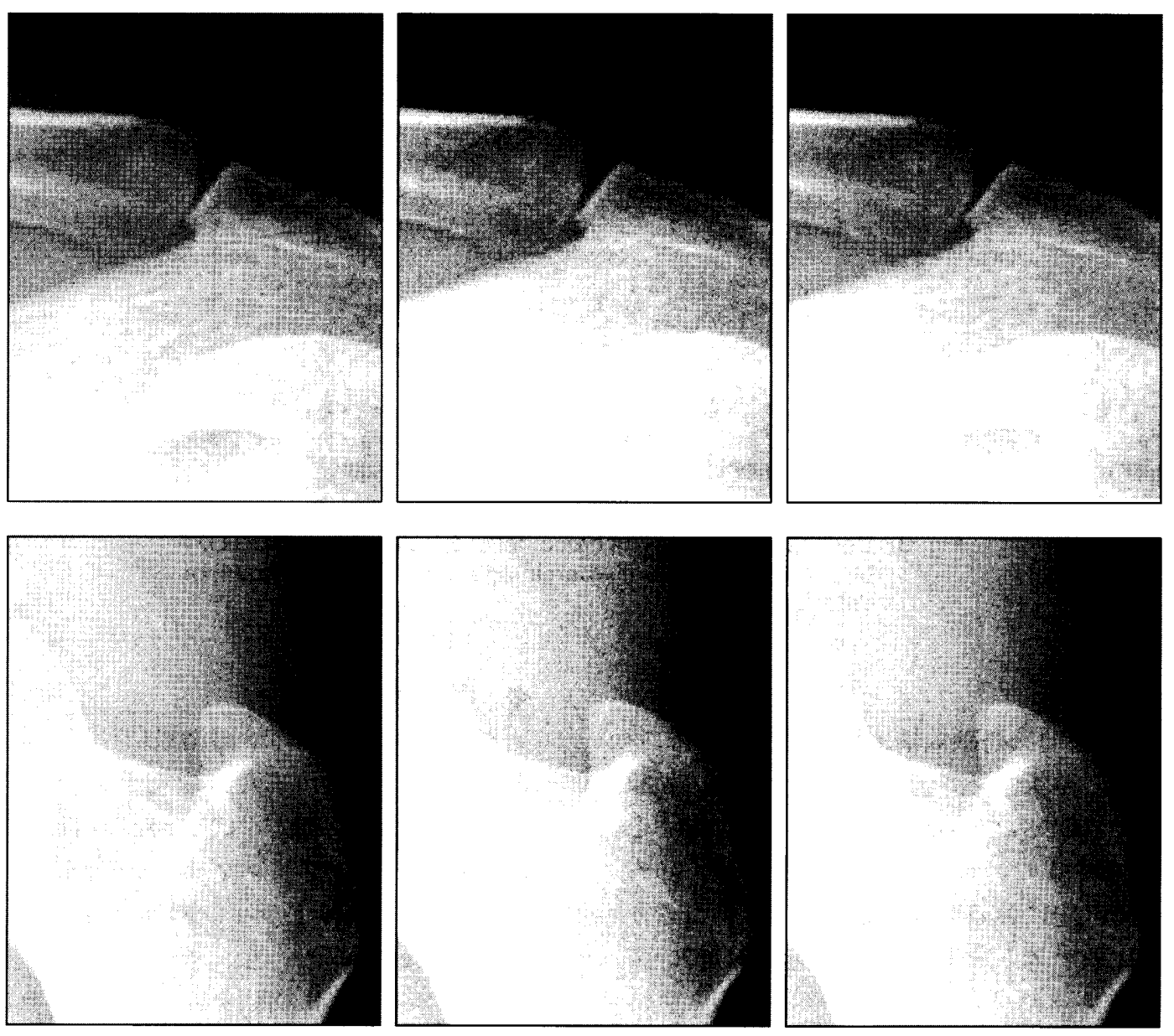

Fig. 9 Example of image used as sample of pair comparison method.
a) Shoulder joint using GDS-2.
(b) Shoulder joint using GDS-4.
(c) Shoulder joint using GDS-6.
(d) Hip joint using GDS-2.
(e) Hip joint using GDS-4.
(f) Hip joint using GDS-6. 
一般的な頭部夕ウン法では，グリッドに対し入射角 30 40落使用される。しかし，実際の撮影では被写 体の大きさや位置，また，X線束とグリッドラインの アライメントのずれにより，グリッドラインのスペク トルピークが低くなる可能性がある。 そこで，今回の

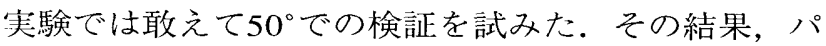
ワースペクトルは今回の実験中最も低い值を示した が, ROIの選択要件から, 検出領域にはグリッドライ ンの強度が強く現れる領域が選択されることと，通常 の入射角度が今回の実験よりも小さいことからパワー スペクトルの最大值はより高い值となり，実際の撮影 においてもグリッドライン検出は期待できるものと考 える。

グリッドライン抑制の物理評洒に扔ける試料の選定 について，本来のグリッドの適用を考えると，今回の ような評価には，腹部など散乱X線の影響を受けやす い部位のデー夕を使用するべきである。しかし，その ような部位で描出されるグリッドラインは，被写体厚 の薄い部位と比較して散乱X線の影響によりパワース ペクトルが弱められることが予測される。

そのため, 腹部などの被写体厚の厚い部位を選択し て実験を進めた場合，より小さなGDSパラメータでも 十分な抑制効果が得られる結果につながる可能性があ り，撮影部位や環境により，強いパワースペクトルを 持つグリッドラインが描出された場合，十分な抑制効 果が得られるかどうかの疑問が残ることとなる。

そこで，本来グリッドを使用せずに撮影可能な散乱 X線の影響を受けにくい部位であり，腹部などの部位 と比較してグリッドラインのパワースペクトルのピー クが強く現れ，縞目陰影やエリアシング現象による障 害が生じやすいと考えられることから膝関節のデー夕 を選択した．Fig. 10に散乱X線の影響を受けやすい部 位として腰椎画像と, 今回の評価に使用した膝関節画 像におけるグリッドラインの描出の变化を示す.

周波数解析の結果，GDSはグリッドラインのパワー スペクトルを抑制すると同時に，周辺の周波数領域に も影響を及ぼすことが分かった。これは，ノッチフィ ルタにおけるギブス現象の影響を低減するため不可欠 とも考えられ，いたずらに大きなパラメー夕を使用す ることは避けるべきである。

2-AFC法を用いた評価では，GDS-5付近で視覚上グ リッドラインを認識することがほぼ不可能となること が判明し，GDS-4まなは 5 を選択することで十分なグ リッドライン抑制効果が得られていると考えられる.

続いて行った一対比較法による画質評価では, 2AFC法において $85 \%$ の観察者がグリッドラインを認識 するGDS-2に加え，ほぼ認識不能となるGDS-6に执い ても，試料とした 5 部位についてその画質には変化が
みられなかった。

グリッドライン検出の検証結果から，日常業務で想 定されるグリッドの使用状況であればGDSの検出機能 は十分に有効であり，格子比8：1・密度 $34 \mathrm{lp} / \mathrm{cm}$ の汎 用グリッドを使用したグリッドライン抑制の検証結果 から，画質に变化はみられないものの，抑制機能が空 間周波数に与える影響を考慮すると, GDS-3〜5が日 常業務のなかで使用するうえでの適切な值であると考 えられる。

一般的に理想的なグリッドの性能とは，コントラス 卜改善度が高く露出倍数が小さいものとされており， 低密度グリッドと同等のコントラストを確保し，ほぼ 同一の露出倍数とするには, 低密度グリッドの 1 ラン ク上のグリッド比を選択する必要があるとされる8, 91. グリッドラインが視覚上目立ちやすいという低密度グ リッドの欠点を, GDSの機能が補うことが可能である と考えると, グリッドを選択する際に, 敢えて高価格 な高密度グリッドを求めるのではなく, 価格や性能を 優先するなど選択の自由度を広げるものと思われる。

GDSの有する機能を考えると，モニ夕表示における モアレ発生時に有効であることが予測される。しか し，モニタに拈けるモアレの発生要因にはさまざまな パラメータが影響し，今回の研究だけで結論付けるこ とはできない。そこで，われわれの施設に㧍いて確認 することのできた，GDSによるモニ夕上での画質の変 化を参考までに記述する。

Fig. 11はコダックDICOMビューアーAutoRadで表示 したGDS OFFとGDS-4の股関節軸位像 (8:1 ・

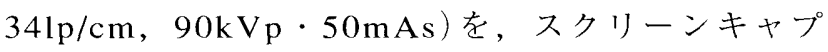
チャーソフトを使用して取り込んだものであり，使用 したビューアーの画像表示に関するハードウェアは, グラフィックチップIntel815，表示解像度 $1024 \times 1280$ 。 リフレッシュレート75Hz，モニタNEC Multi Sync LCD2010Xである.

GDS OFFに扔けるモアレは，モニ夕表示信号とグ リッドラインの干渉によるものであり，表示するハー ドウェア，あるいは解像度や拡大率により異なる。し かし, GDS-4の画像については, 本研究に使用した数 台のPCにおいても，また，表示するサイズを変更し てもモアレの発生を確認することはなかった。このこ とは，モアレ発生の一つの要因であるグリッドライン が十分に抑制されていることの証明といえる.

今回の一対比較法に使用した試料について, ビュ一 アーでの表示を確認したところすべての試料に扔い て，GDS-2ではグリッドラインがわずかに観察できる ものの，モアレ状の陰影は消失し，GDS-3ではグリッ ドラインを確認することもほぼ不可能であった。

2005 年 8 月 

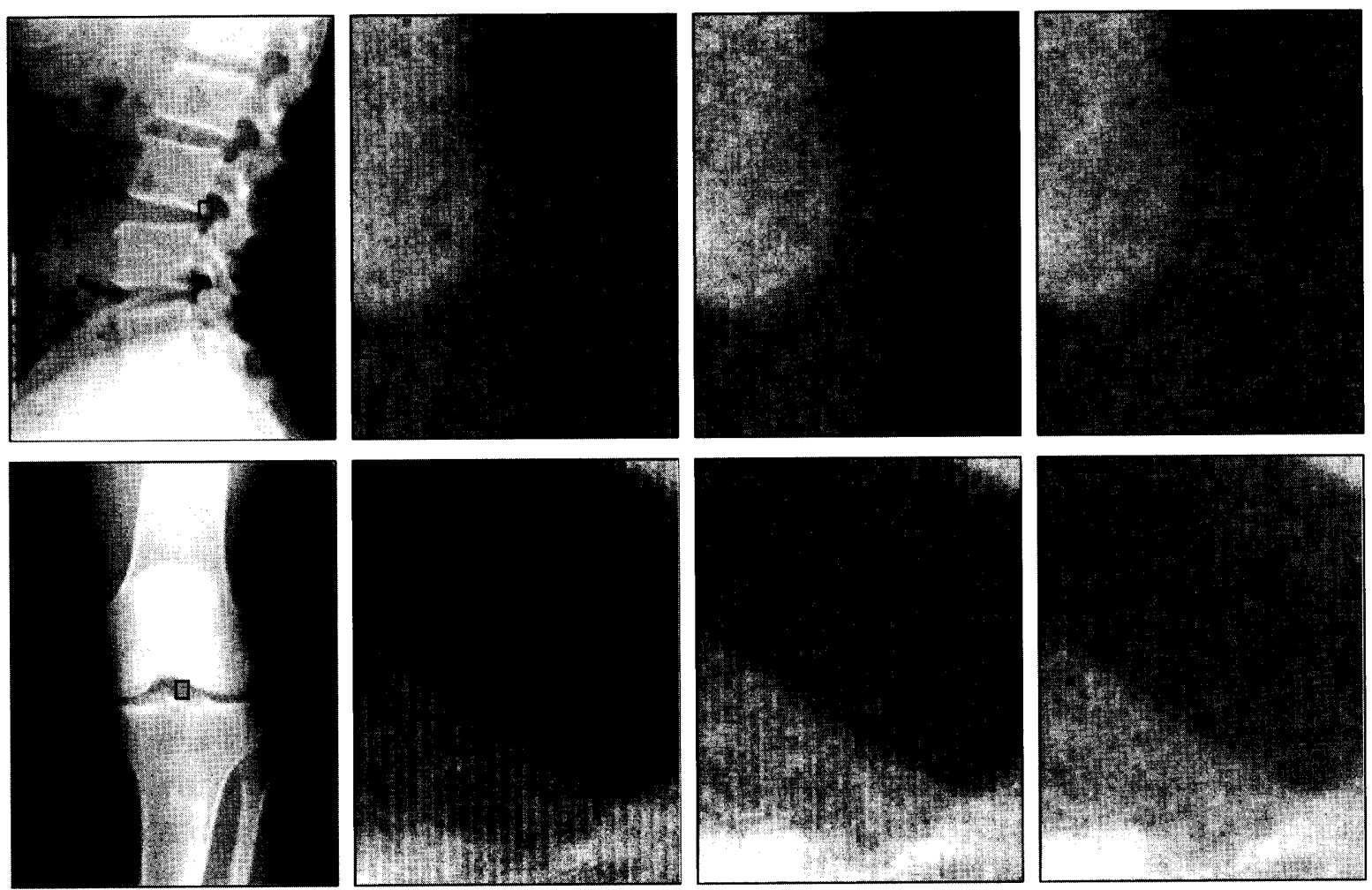

Fig. 10 Comparison of grid line visibility depending on the difference of scattered $X$ ray amount.

(a) Original image of vertebrae lumbales.

(b) Vertebrae lumbales GDS OFF.

(c) Vertebrae lumbales using GDS-1.

(d) Vertebrae lumbales using GDS-2.

(e) Original image of knee joint.

(f) Knee joint GDS OFF.

(g) Knee joint using GDS-1.

(h) Knee joint using GDS-2.

\section{5. 結 語}

今回の研究テーマとしたGDSは，グリッドラ インを自動的に検出し抑制することを目的とし たソフトウェアであり，日常業務の自動処理と してGDSを使用する場合，GDS-3－5を標準と することでさまざまなグリッド使用状洗に対応 できると考える。

このようなソフトウェアが普及することは， デジタル画像処理におけるグリッドの選択範囲 を広げるとともに，モニ夕診断におけるハード ウエア選択を容易にすると考えられ，X線画像 のデジタル化と, 画像ネットワークの普及を進 める要因になりえるものと考える。
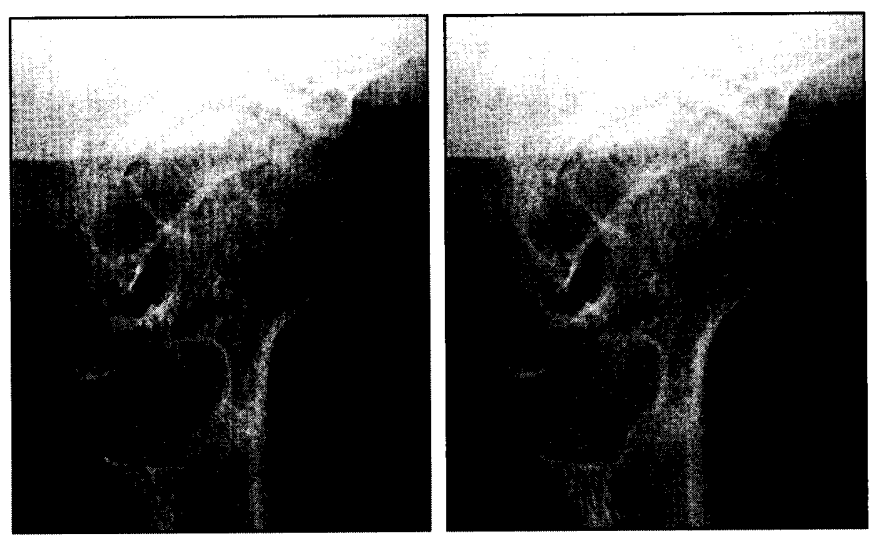

Fig. 11 Hip joint axial image of monitor display.
(a) GDS OFF.
(b) Using GDS-4

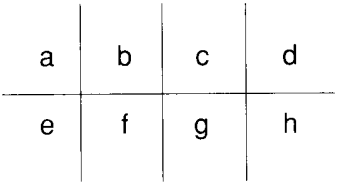

\section{謝 辞}

今回の研究にあたり，ご多忙中にもかかわらず環境 測定にご協力いただいた株式会社森山X線用品 森山 氏，ならびに，視覚評価にご参加いただいた放射線科

な㧍，本論文の要旨は，日本放射線技術学会 第59 赤田・朴両医師掞よび整形外科 宮川・香取両医師に 深く感謝いたします。 


\section{参考文献}

1) 三上直樹：ディジタル信号処理の基礎. pp.21, CQ出版, 東京, (1998).

2) 坂巻佳壽美：見てわかるディジタル信号処理. pp.35, 工業 調查会, 東京, (1998).

3) Belykh IN, and Cornelius CW: Antiscatter stationary grid artifacts automated detection and removal in projection radiography images. Proc SPIE, 4322, 1162-1166,(2001).

4) Barski LL, and Wang X: Characterization detection and suppression of stationary grids in digital projection radiography imagery. Proc SPIE, 3658, 502-520, (1999).
5) Oppenheim AV, and Schafer RW: Digital signal processing. Englewood Cliffs, NJ: Prentice-Hall, (1975).

6) 大塚昭義, 砂屋敷忠, 小寺吉衙編: 実験 画像評価一初学 者のための実験入門書. pp.71-80, 日本アクセル・シュプ リンガー出版, 東京, (1994).

7) 日科技連官能検查委員会編：新版官能検査ハンドブッ ク. pp.349-391, 日科技連出版社，東京，(1973）

8) JIS Z 4910-1983

9) 三田屋商事 資料

\section{図表の説明}

Fig. 1 GDS検出プロセスのフローチャート

Fig. 2 (a) 原画像
(b)GDSが自動的に決定した検出領域(灰色枠部分) 㧍よび検出領域から除外された領域(黒枠部分)

Fig. 3 一次元FFTによるパワースペクトル解析過程

Fig. 4 ノッチフィルタに扔ける帯域阻止幅(バンドストップ幅)と画像情報への影響

(a) バンドストップ幅 $\mathrm{A}$ 一抢よびB--ー $(\mathrm{A}<\mathrm{B})$

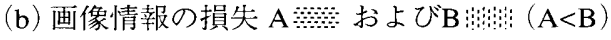

(c) ギブス現象の影響を受ける領域 $\mathrm{A} \bigcirc$ and $\mathrm{B} \square(\mathrm{A}>\mathrm{B}$ )

Fig. 5 (a) 原画像

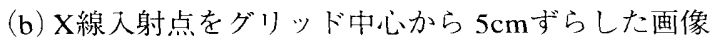

(c) カセッテに対しグリッドを $45^{\circ}$ 回転させた画像

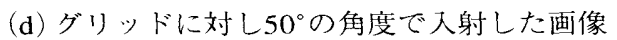

Fig. 6 膝関節正面画像に拈けるパワースペクトル
(a) GDS OFF扩よびGDS-7，16使用時

(b) GDS-2， 4 および 6 使用時

Fig. 7 膝関節正面内側部の拡大画像
(a)グリッドなし
(b) GDS-16使用時
(c) GDS-7使用時

Fig. 8 GDS-7の写真を比較基準とした場合の2-AFC法におけるGDS OFFおよびGDS-1〜6のグリッドライン認識結果

Fig. 9 一対比較法の試料として使用した写真の例
(a) 肩関節 GDS-2使用時
(b) 肩関節 GDS-4使用時
(c) 肩関節 GDS-6使用時
(d) 股関節 GDS-2使用時
(e) 股関節 GDS-4使用時
(f) 股関節 GDS-6使用時

Fig. 10 散乱X線の影響を受けやすい部位と受けにくい部位でのグリッドライン描出の比較
(a) 腰椎 原画像
(b) 腰椎 GDS OFF
(c) 腰椎 GDS-1使用時
(d) 腰椎 GDS-2使用時
(e) 膝関節 原画像
(f) 膝関節 GDS OFF
(g) 膝関節 GDS-1 使用時
(h) 膝関節 GDS-2使用時

Fig. 11 モニタ表示における股関節軸位像
(a) GDS OFF
(b) GDS-4使用時

Table 1 GDSパラメータとスペクトルパワー減衰量(設定值)

Table 2 使用装置一覧

Table 3 CR800に扔けるカ七ッテサイズとサンプリングピッチの関係

Table 4 グリッドの配置によるグリッドライン検出の結果

Table 5 各計算領域におけるグリッドライン周波数

Table 6 (a) 局関節の微細構造物描出度評価における信頼区間

(b) 肩関節の軟部組織粒状性評価に扔ける信頼区間

使用したGDSパラメータをGDS-2： $\alpha_{l}$, GDS-4： $\alpha_{2}$, GDS-6： $\alpha_{3}$ に示す. 